\title{
CORRECTION
}

View Article Online

View Journal I View Issue

CrossMark

\& click for updates

Cite this: J. Mater. Chem. A, 2016, 4, 18188

DOI: $10.1039 / c 6 t a 90231 f$

www.rsc.org/MaterialsA

There are errors in Table 1 of the above manuscript. The correct Table 1 is copied below.

Table 1 Lattice vectors ( $a$ and $b$ in $\AA$ ), angle ( $\gamma$, in degrees) and surface area ( $S$ in $\AA^{2}$ ) of the optimized YSZ-LiKCO 3 interface model together with its adhesion energy $\left(E_{\text {ads }}\right.$ in eV), specific adhesion energy $\left(\beta_{\text {ads }}\right.$ in eV $\left.\AA^{-2}\right)$, and band gap $\left(E_{\mathrm{g}}\right.$ in eV)

YSZ- $-\mathrm{LiKCO}_{3}$ interface

$b$

$\gamma$

$S$

$E_{\text {ads }}$

$\beta_{\text {ads }}$

$E_{\mathrm{g}}$

The Royal Society of Chemistry apologises for these errors and any consequent inconvenience to authors and readers.

\section{Correction: Modeling composite electrolytes for low-temperature solid oxide fuel cell application: structural, vibrational and electronic features of carbonate-oxide interfaces}

Chiara Ricca, ${ }^{a}$ Andrey Grishin, ${ }^{a}$ Armelle Ringuedé, ${ }^{a}$ Michel Cassir, ${ }^{a}$ Carlo Adamo ${ }^{a b}$ and Frédéric Labat ${ }^{\star a}$

Correction for 'Modeling composite electrolytes for low-temperature solid oxide fuel cell application: structural, vibrational and electronic features of carbonate-oxide interfaces' by Chiara Ricca et al., J. Mater. Chem. A, 2016, DOI: 10.1039/c6ta06827h.

7.17
6.27
90.10
45.01

